
Not for reproduction, distribution or commercial use.

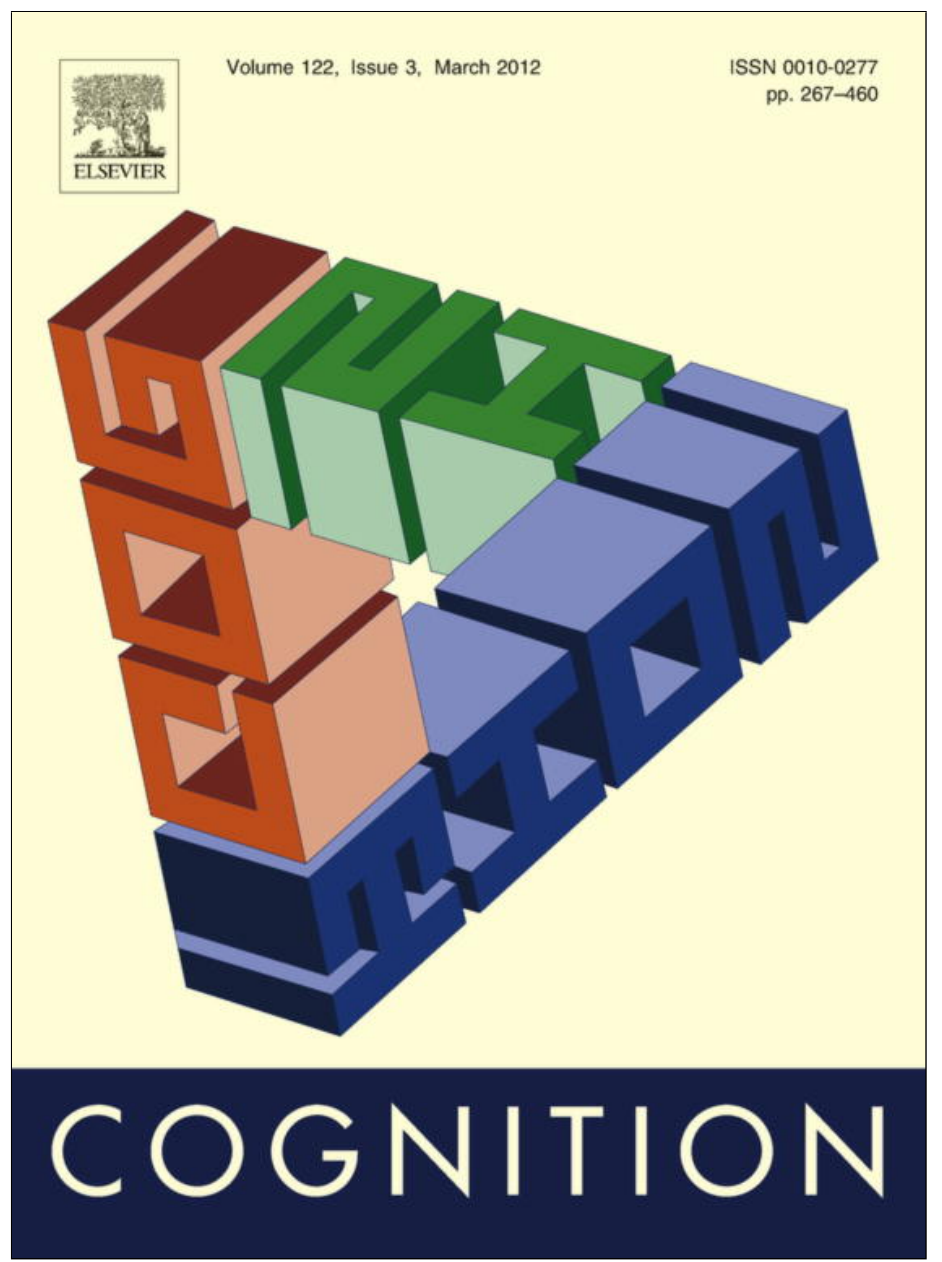

This article appeared in a journal published by Elsevier. The attached copy is furnished to the author for internal non-commercial research and education use, including for instruction at the authors institution and sharing with colleagues.

Other uses, including reproduction and distribution, or selling or licensing copies, or posting to personal, institutional or third party websites are prohibited.

In most cases authors are permitted to post their version of the article (e.g. in Word or Tex form) to their personal website or institutional repository. Authors requiring further information regarding Elsevier's archiving and manuscript policies are encouraged to visit:

http://www.elsevier.com/copyright 


\title{
Temporal and spatial relations in sentential reasoning
}

\author{
Csongor Juhos ${ }^{\mathrm{a}, *}$, Ana Cristina Quelhas ${ }^{\mathrm{a}}$, P.N. Johnson-Laird ${ }^{\mathrm{b}}$ \\ ${ }^{a}$ ISPA - Instituto Universitário, Lisbon, Portugal \\ ${ }^{\mathrm{b}}$ Princeton University, Department of Psychology, Princeton, New Jersey, United States
}

\section{A R T I C L E I N F O}

\section{Article history:}

Received 17 October 2011

Accepted 14 November 2011

Available online 10 December 2011

\section{Keywords:}

Temporal reasoning

Spatial reasoning

Modulation

Mental models

\begin{abstract}
A B S T R A C T
The mental model theory postulates that the meanings of assertions, and knowledge about their context can modulate the logical meaning of sentential connectives, such as "if" and "or". One known effect of modulation is to block the representation of possibilities to which a proposition refers. But, modulation should also add relational information, such as temporal order, to models of possibilities. Three experiments tested this prediction. Experiment 1 showed that individuals spontaneously matched the tense of their conclusions (in Portuguese) to embody implied, but unexpressed, temporal relations in conditional premises. Experiment 2 demonstrated the same phenomenon in inferences from disjunctions. Experiment 3 showed that the number of such implicit relations in inferences from conditionals affects both accuracy and the speed of reasoning. These results support the modulation hypothesis.
\end{abstract}

(c) 2011 Elsevier B.V. All rights reserved.

\section{Introduction}

A common psychological observation is that many sentential connectives have more than one interpretation. Conditionals with an "if_then_" structure are a paradigm case (Braine, 1978; Evans \& Over, 2004; Johnson-Laird \& Byrne, 2002; Rips, 1994). The reader is invited to consider, for instance, two simple inferences:

1. If the client makes an order then the goods are shipped.

The goods are shipped.

What follows?

Individuals tend to infer:

The client made the order. (An inference known as

Affirmation of the Consequent: AC.)

2. If the client makes an order then the goods are shipped.

\footnotetext{
* Corresponding author. Address: Instituto Superior de Psicologia Aplicada, Instituto Universitário, Rua Jardim do Tabaco, 34, 1149-041 Lisboa, Portugal. Fax: +35121881 1700

E-mail address: cjuhos@ispa.pt (C. Juhos).
}

The client makes an order.

What follows?

Individuals tend to infer:

The goods are shipped. (An inference known as

Modus Ponens: MP.)

There is a subtle difference between the two conclusions. The AC conclusion is in the past tense, whereas the MP conclusion is in the present tense, which is a natural way to refer to an event in the future in English, because English has no future tense. The difference in the two conclusions illustrates what we refer to as "temporal modulation", and the aim of the present article is to investigate this aspect of the theory of mental models. It accordingly begins with an account of how models represent temporal relations and how modulation works.

Mental models can represent temporal relations in a sequence of models organized on a temporal axis (or "time line"; see Johnson-Laird, 1983, chap. 15). An assertion, such as, "After the plane flew through the storm, the pilot radioed the tower," calls for models that we represent in the following diagram:

f $r u$ 
in which the temporal axis runs from left to right, $f$ denotes a model of the plane flying through the storm, $r$ denotes a model of the pilot radioing the tower, and $u$ denotes the time of the sentence's utterance. The sequence of models establishes that the two events represented by $f$ and $r$ occurred in the past with respect to the time of utterance (see, e.g., Miller \& Johnson-Laird, 1976, sec. 6.2). The symbols $f$ and $r$ denote mental models of events, and their structure does not concern us here (but see, e.g., Johnson-Laird \& Byrne, 1991). What does matter is that events can be conceived and described as either momentary or as having durations, definite or indefinite. Hence, $f$ represents an event having a duration that ends at some point prior to the one in $r$. A corollary is that the representation must allow for overlaps and other sorts of relations among concurrent events (see, e.g., Allen \& Ferguson, 1994). A computer program that makes temporal inferences using sequences of models is at http://mentalmodels.princeton.edu/models/. And several experimental studies have examined explicit temporal inferences, showing that inferences calling for multiple representations are harder than those calling for a single representation (e.g., Schaeken, Johnson-Laird, \& d'Ydewalle, 1996a). This phenomenon also occurs when assertions convey a temporal sequence solely in their tense and aspect, e.g.: John has cleaned the house; John is taking a shower; John is going to read the paper (Schaeken, Johnson-Laird, \& d'Ydewalle, 1996b). The model theory accordingly explains the representation of temporal relations in terms of the location of models on a time line - a feature that can be used to run a kinematic simulation of events, though not necessarily in terms of their real durations (Goodwin \& Johnson-Laird, submitted for publication).

Modulation is a prediction of the model theory according to which the meanings of clauses, what they refer to, and general knowledge can modify the interpretation of sentential connectives, such as "if" and "or" (Johnson-Laird \& Byrne, 2002). Consider, first, a case in which modulation is unlikely to occur:

\section{If Pat is here then Viv is here.}

The interpretation of this conditional assertion is likely to be logical, that is, it refers to three possibilities, where $p$ denotes Pat being here, $v$ denotes Viv being here, and $\neg$ is a symbol for negation:

$$
\begin{array}{rr}
p & v \\
\neg \mathrm{p} & v \\
\neg \mathrm{p} & \neg \mathrm{V}
\end{array}
$$

So, we can paraphrase the assertion as: If Pat is here then Viv is here, and if Pat is not here then Viv may, or may not, be here. In other words, the assertion rules out only the possibility in which Pat is here, but Viv is not. However, individuals normally represent conditionals in two mental models (Johnson-Laird \& Byrne, 2002). One model makes explicit the case in which both clauses are true, and the other model, denoted here by the ellipsis, has no explicit content but allows for other possibilities (in which the ifclause is false):

\section{p v}

Only in certain circumstances do individuals flesh out these mental models into fully explicit models corresponding to the three possibilities shown above.

One such circumstance is when conditionals elicit relevant knowledge, e.g.:

If the client makes an order then the goods are shipped. Individuals know that firms do not normally ship goods to a client unless the client has ordered them. The theory postulates that this sort of knowledge is represented in fully explicit models in long-term memory:

$$
\begin{array}{rr}
M & G \\
\neg \mathrm{M} & \neg \mathrm{G}
\end{array}
$$

This diagram denotes models of two possibilities, $M$ denotes a model of a person making an order, $G$ denotes a model of a firm shipping the order, and once again the time line runs from left to right in this diagram. We use the notational convention here that capital letters denote states of affairs in general, i.e., they represent general propositions. Modulation is the process of forming the pairwise conjunction of each mental model of an assertion with each fully explicit model in long-term memory, which the mental models trigger by way of their contents. By default, knowledge takes precedence in the process. In the present case, the result is the following two models of the conditional assertion, where the lower case symbols denote specific instantiations of the models of general propositions in knowledge, and the time line again runs from left to right:

$$
\begin{array}{rr}
m & g \\
\neg \mathrm{m} & \neg \mathrm{g}
\end{array}
$$

So, the effect of modulation is to yield the fully explicit models of a biconditional ("if and only if"), and to arrange the models in an appropriate sequence on the time line. Modulation can yield the opposite temporal order, e.g., "If Mauro did well on the exams, then he studied a lot", because individuals know by default that study precedes exams. Default inferences are ones in which individuals draw conclusions unless there is information to the contrary. Hence, the inference that the client makes an order before the goods are shipped could in principle be overruled by further information, e.g., about a special arrangement between the client and the firm. Previous experiments have shown that individuals make various interpretations of conditionals as a result of modulation, including temporal modulation, and that as a consequence they can answer explicit questions about the temporal order of events (Quelhas, Johnson-Laird, \& Juhos, 2010).

The general principles of modulation are straightforward. Its algorithm depends on the pairwise conjunction of fully explicit models in long-term memory with the mental models of a current assertion, and by default the fully explicit models take precedence over the mental models in the case of conflicts. The algorithm has been implemented in a computer program, which has been 
described in detail elsewhere (see Johnson-Laird, Girotto, \& Legrenzi, 2004).

One final factor remains to be accounted for in the interpretation of the premises for the earlier inference affirming the consequence $(\mathrm{AC})$ :

If the client makes an order then the goods are shipped. The goods are shipped.

The categorical premise eliminates the possibility in which the goods are not shipped and the client does not make an order. But, the categorical premise also marks the time of utterance, $u$, and so individuals should build the following time line:

\section{$m \quad g$}

$u$

The client's order was accordingly made prior to the time of utterance, and so reasoners should draw a conclusion in the past tense:

The client made the order.

When individuals represent the premises of a modus ponens (MP) inference:

If the client makes an order then the goods are shipped. The client makes an order.

the categorical premise also marks the time of utterance. So, the time line is:

$$
m \quad g
$$

$u$

Individuals should therefore draw a conclusion in the present tense in order to express a future event:

The goods are shipped.

In summary, temporal modulation predicts a difference between the two inferences. The AC conclusion should be in the past tense, whereas the MP conclusion should be in the present tense, which is a natural way to refer to an event in the future, both in English and in Portuguese (the language in which our experiments were carried out). The model theory predicts this difference, because the AC conclusion refers to an event earlier in time than the one in the categorical premise at the time of utterance, whereas the MP conclusion refers to an event later in time than the one in the categorical premise at the time of utterance. The present paper reports three experiments showing that individuals frame their conclusions spontaneously in the appropriate tenses for such temporal relations.

\section{Experiment 1}

The experiment tested the model theory's prediction that reasoners should infer temporal relations in reasoning from conditionals. They should spontaneously use the past tense to refer to an event prior to one in a categorical premise, but the present (or future) tense to refer to an event subsequent to one in a categorical premise. Unlike English, Portuguese has a future tense, though the language also allows speakers to use the present tense to refer to future events.

\subsection{Method}

\subsubsection{Participants}

The participants were 40 undergraduates, native speakers of Portuguese, from ISPA Instituto Universitário, Lisbon (Age $M=21.92$ years; $7 \mathrm{M}, 33 \mathrm{~F}$ ), who participated for course credit.

\subsubsection{Design}

The participants drew their own conclusions from 48 pairs of premises of four sorts presented to each of them in a different random order. Given the conditional premise (translated, as are all the materials, from the Portuguese):

If the client makes an order then the goods are shipped.

the four sorts depended on different categorical premises presented on separate trials:

1. The client makes an

(Modus ponens: MP) order.

2. The client does not make an order.

(Denial of the

3. The goods are shipped. antecedent: DA)

4. The goods are not shipped.

(Affirmation of the consequent: $\mathrm{AC}$ ) (Modus tollens: MT)

For the MP and DA inferences, individuals should tend to draw conclusions in the present or in the future tense, but for AC and MT inferences, they should tend to draw conclusions in the past tense. In order to check that differences in tense are not attributable to the order of the clauses, half of the problems used conditionals of the grammatical form, if $A$ then $B$, and half of the problems used conditionals of the grammatical form, $B$ if $A$. In 24 problems, modulation should yield a temporal order: the if-clause referred to an earlier event than the one referred to in the then-clause. In the remaining 24 control problems, the conditionals did not imply a temporal order, e.g.: "If the office is in Moscow, then the clinic is in London".

\subsubsection{Materials}

The 48 inferences were based on 12 conditionals (in Portuguese): six should elicit a temporal order in which the situation in the if-clause preceded the situation in the-then clause, and four did not, as in the preceding example. The materials and translations of the materials in this and our subsequent experiments are in Appendix A, and they are also downloadable at: http://mentalmodels.princeton.edu/misc/Materials25Set2011.doc. Each conditional occurred in the four sorts of inference, depending on whether the if-clause or the then-clause was asserted 
or denied in a categorical premise. All the categorical premises were presented in the present tense.

\subsection{Procedure}

The problems were presented in booklets and the key instructions, stated on the first page, were: "Your task in this experiment is to draw a conclusion based on each set of sentences that you will find on the pages of this booklet". Each page contained a contextualized conditional premise, a categorical assertion, and a space to write down a conclusion as the example shows:

The doctor says that:

If the patient takes an antipyretic drug then the fever goes down.

We know that:

The patient takes an antipyretic drug.

Therefore,

\section{Results}

The participants drew conclusions on $82 \%$ of trials. The overall percentages for the four sorts of inference were MP $88 \%$, DA $78 \%$, AC $84 \%$, and MT 78\%. The dependent variable was the tense of the verb in a conclusion, which is marked by a suffix in Portuguese, e.g., desce ("descends" in the present tense), desceu (in the past tense), descerá (in the future tense). No reliable difference occurred between the two grammatical forms if $A$ then $B$ (28\% past tense) and $B$ if $A$ (26\% past tense; Wilcoxon test, $z=.98, p=.33$ ), and so we collapsed the data from these two conditions. The percentages of conclusions in the past tense corroborated the model theory's predictions:

Forwards inferences from temporal conditionals 3\% (MP and DA):

Backwards inferences from temporal $97 \%$ conditionals (MT and AC):

Forwards inferences from control conditionals $\quad 4 \%$ (MP and DA):

Backwards inferences from control conditionals 12\% (MT and AC):

In the balance of the percentages, $37 \%$ of forwards inferences from temporal conditionals elicited the present tense and $60 \%$ elicited the future tense; $3 \%$ of backwards inferences from temporal conditionals elicited the present tense; $61 \%$ of forwards inferences from control conditionals elicited the present tense and 35\% elicited the future tense; $80 \%$ of backwards inferences from control conditionals elicited the present tense and $8 \%$ elicited the future tense. The past tense occurred more often in conclusions from temporal than from control conditionals (Wilcoxon test $z=5.50 ; p<.000$ ). It also occurred more often for MT and AC than for MP and DA (Wilcoxon test $z=5.51$; $p<.000$ ). But, the interaction was highly significant: the bias to use the past tense for MT and AC was reliably larger for backwards temporal conditionals than for control conditionals (Wilcoxon test, $z=5.52, p<.000$ ). An analysis of variance confirmed the results of the non-parametric tests. The past tense occurred more often in conclusions from temporal conditionals than from control conditionals $(F(1,39)=835.62 ;$ Mse $=83.59 ; p<.000)$. It also occurred more often for MT and AC than for MP and DA $(F(1,39)=1626.251$; Mse $=60.24 ; p<.000)$. But, the interaction was highly significant: the bias to use the past tense for MT and AC was reliably bigger for backwards temporal conditionals than for control conditionals $(F(1,39)=$ 1227.744; Mse =61.54; $p<.000$ ).

\section{Experiment 2}

This experiment aimed to extend the phenomena to disjunctive inferences. Individuals spontaneously infer conditionals from disjunctions (Van der Henst, Yang, \& Johnson-Laird, 2002), and they also do so in deliberate paraphrases (Ormerod \& Richardson, 2003), e.g.:

Either Luís closes the deal or he is fired.

Therefore, if Luís doesn't close the deal, then he is fired.

In both assertions, modulation yields a temporal relation: Luís's closing the deal or failing to do so (at the appropriate time) occurs prior to his being fired or not. This order predicts the same pattern of tenses in spontaneous conclusions from disjunctions as occurred from conditionals in the previous experiment. In a backwards inference, such as:

Either Luís closes the deal or he is fired.

Luís is fired.

What follows?

participants should use the past tense in infer that Luís did not close the deal. The experiment examined temporal inferences with conditionals and disjunctions, and inferences from control assertions that should not yield temporal relations.

\subsection{Method}

\subsubsection{Participants}

The participants were 32 undergraduates from the same population as before (age $M=20.47$; F 26, M 6).

\subsubsection{Design}

The participants drew their own conclusions from 16 problems based on conditionals and 16 problems based on disjunctions. There were four sorts of inference for conditionals (MP, AC, MT and DA) and four equivalent inferences for disjunctions, i.e., they had the same categorical premises as those in the conditional inferences. In half the inferences, the major premise implied that the event in the first clause occurred before the event in the second clause, and in half the inferences the major premise had no temporal implication.

\subsubsection{Materials and procedure}

The procedure was the same as in Experiment 1. We used the same contents in both sorts of assertion. Half the conditionals had negative if-clauses and the 
corresponding disjunctions were affirmative; and half the conditionals had affirmative if-clauses and the corresponding disjunctions had negative first clauses. The corresponding pairs, however, referred to persons with different names. The materials are in the Appendix A.

\section{Results}

The participants drew conclusions for $94 \%$ of the problems. They hardly ever used the past tense for conclusions drawn from premises that did not imply a temporal order ( $4 \%$ overall). The percentages of conclusions in the past tense corroborated the model theory's predictions:

Forwards inferences from temporal conditional $6 \%$ (MP and DA):

Backwards inferences from temporal conditional (MT and AC):

Forwards inferences from temporal disjunctions:

Backwards inferences from temporal disjunctions:

$9 \%$

$74 \%$

The frequency of the past tense with conditional inferences was reliably higher then disjunctive inferences $(29 \%, 17 \%$, Wilcoxon test, $z=4.01, p=.000$ ), and we therefore analyzed the results for conditional and disjunctive inferences separately.

With conditional inferences, the participants used the past tense more often when the main premise implied a temporal relation than when it did not, and the interaction was reliable: The bias to use the past tense for backwards inferences was reliably larger for temporal premises than for the control premises (Wilcoxon test, $z=4.16$, $p<.000)$. An analysis of variance also confirmed the results of the non-parametric tests. The participants used the past tense more often when the main premise implied a temporal relation than when it did not $(F(1,31)=40.862$; Mse $=1.023 ; p<.000)$. They also used it more often for backwards inferences than for forwards inferences $(F(1,30)=92.719$; Mse $=1.015 ; p<.000)$. And their bias to use the past tense for backwards inferences was reliably larger for temporal premises than for the corresponding control premises $(F(1,30)=39.229$; Mse $=.599 ; p<.000)$.

The same pattern of results occurred with disjunctive inferences. The participants used the past tense more often when the main premise implied a temporal relation than when it did not, and the interaction was reliable: Their bias to use the past tense for backwards inferences was reliably larger for temporal premises than for the comparable control premises (Wilcoxon test, $z=3.78, p<.000$ ). An analysis of variance also confirmed the results of the non-parametric tests. The participants used the past tense more often when the main premise implied a temporal relation than when it did not $(F(1,48)=72.099 ;$ Mse $=.473 ; p<.000)$. They also used it more often for backwards inferences than for forwards inferences $(F(1,48)=37.975 ; \quad$ Mse =.739; $p<.000)$. And their bias to use the past tense for backwards inferences was reliably larger for temporal premises than for the corresponding control premises $(F(1,48)=32.995$; Mse $=.687 ; p<.000)$.

\section{Experiment 3}

Modulation can yield both a temporal and a spatial relation, as in the conditional:

If the infection reaches the knee then it spreads to the ankle.

The conditional implies that the infection affects the knee and then the ankle, and also that it spreads downwards from one to the other. It is not possible to test for spontaneous spatial inferences in English or Portuguese, because they have no way of marking a spatial relation in a suffix akin to tense. But, given that each inference places a processing load on the system, it follows that if modulation yields these inferences, reasoners should be faster and more accurate in answering questions about a single relation when the premises elicit a single relation, either temporal or spatial, than when the premises elicit both these relations.

\subsection{Method}

\subsubsection{Participants}

The participants were 105 students from the same population as before (age $M=22.58 ; \mathrm{F} 85, \mathrm{M} 20$ ).

\subsubsection{Design}

Participants answered questions about a single relation for 16 problems. Four problems implied a temporal relation, e.g.:

If the electrician touches the wire, then he gets a shock in his hand.

If the electrician gets a shock in his hand, then he swears. The electrician touches the wire.

Did the electrician touch the wire before he swore?

Four problems implied a spatial relation in a similar sort of inference; four problems implied both a temporal and a spatial relation, and the question concerned the temporal relation; and four problems implied both a temporal and a spatial relation, and the question concerned the spatial relation. The length of the questions for all problems was carefully controlled in Portuguese. On average the questions had 21 syllables and the standard deviation of syllabic length did not reach one syllable $(S D=.77)$. This precaution is lost in translation into English. In the experiment, each question was presented equally often with both relational terms (before and after, or above and below) so that the correct answers were "yes" on half the trials, and "no" on half the trials. Each set of premises had eight different questions, which occurred equally often in the experiment as a whole. One question from the set was assigned to a given participant in a counterbalanced way, so that he or she received one question for each of the eight sorts of problem in a random order.

\subsubsection{Materials and procedure}

To create the specific content of the problems we used the same procedure as in the previous experiments. The complete materials are in the Appendix A. The experiment was carried out on computers running the E-prime program, and the procedure was self-paced. Participants 
pressed the space bar to receive each premise, and the premises remained on the screen until the entire set was presented. The last premise was presented with a horizontal line below it indicating that the set was complete. When the participant pressed the space bar, a question replaced the premises. Participants responded "yes" or "no" using color-coded keys. After a response, which the program recorded together with its latency, a blank screen came up for $2 \mathrm{~s}$., and then the next trial began.

\section{Results}

The overall mean of correct responses was 11.9 out of 16 $(S D=2.2)$. As predicted, participants gave more correct answers to single relation problems $(M=6.44$ out of 8 , $S D=1.22$ than to double relation problems $(M=5.5$ out of $8, S D=1.5$; Wilcoxon test $z=5.15 ; p<.000$ ). Likewise, participants responded faster when the conditionals implied one relation between the clauses $(M=4820 \mathrm{~ms}$, $S D=1929 \mathrm{~ms}$ ) than when they implied both relations $(M=5510 \mathrm{~ms}, \quad S D=1982 \mathrm{~ms}$; Wilcoxon test $z=5.82$; $p<.000)$. These results show that modulation, whether it occurs initially or only on the presentation of a question, affects the accuracy and speed of the inferential process. Parametric tests confirmed the results of the non-parametric tests. The participants gave more correct answers to single relation problems $(t(104)=6.114 ; p<.000)$; and they responded faster when the conditionals implied one relation between the clauses $(t(104)=3.830 ; p<.000)$.

\section{General discussion}

When individuals infer a conclusion from a conditional or disjunction and a categorical premise, it is based on the consequences of the two premises. Previous studies have shown that individuals can make explicit inferences about the temporal order of events referred to in such premises (Quelhas, Johnson-Laird, \& Juhos, 2010; Schaeken, Johnson-Laird, \& d'Ydewalle, 1996a, 1996b). But, the present results show that they spontaneously alter the tense of their conclusion - even though there is no logical reason to do so - in a way that reveals that they have gone beyond sentential reasoning to consider the temporal relations between events. Given, say, the premises:

If the patient takes an antipyretic drug then his fever goes down.

His fever goes down.

What follows?

participants in Experiment 1 tended to draw a conclusion in the past tense:

The patient took an antipyretic drug.

But, when the categorical premise was instead:

The patient takes an antipyretic drug.

they used the present tense or the future tense in drawing a conclusion:

His fever goes down.

They also used the present tense in drawing conclusions from control conditionals that do not evoke temporal relations. The same phenomena occurred in Experiment 2 with inferences based on disjunctions. These temporal inferences depend on modulation, which according to the model theory is a process that exploits knowledge - in the form of fully explicit models - to modulate the interpretation of the premises. In our studies, it yielded an interpretation of the events referred to in the premises in a temporal sequence. As Experiment 3 showed, this process exerts a load on the interpretative system. To answer a question takes longer for premises that elicit both temporal and spatial relations than for premises that elicit only one of these relations. Individuals may predict a spatial question from premises that imply only a spatial relation, a temporal question from premises that imply only a temporal relation, and so take longer from premises that imply both relations because they cannot predict what the question will be about. But, even this account presupposes that individuals do use modulation to infer a correct answer.

The results corroborated the predictions of the model theory, and in particular its prediction that the interpretation of sentential connectives, such as "if" and "or", is modulated by the meanings of the clauses that they interconnect, knowledge about what they refer to, and general knowledge (Johnson-Laird \& Byrne, 2002). Other theories of reasoning, such as those based on formal rules of inference (e.g., Braine \& O’Brien, 1998; Rips, 1994), may be able to account for this phenomenon of modulation. But, at present, these theories do not predict it, in part because they focus on matters of pure logic rather than temporal relations between events. It is difficult to capture the uses of tense and aspect without a time line on which to represent events, such as the time of utterance (see, e.g., Miller \& Johnson-Laird, 1976, sec. 6.2). Of course, this argument is hardly decisive, and it may yet be possible to develop an account of our results within a formal theory of reasoning.

The present experiments show that modulation is not limited to blocking the construction of possibilities, but can add temporal and spatial relations to the interpretation of assertions. This possibility is a decisive objection to the view that connectives in natural language are interpreted in a truth-functional way, sensitive only to the truth or falsity of the clauses. Relations in space and time matter too.

Finally, the present results have consequences for "dual process" theories of reasoning, implying that the distinction between automatic intuitive inferences (based on System 1) and deliberate deductions (based on System 2) may stand in need of revision. Many theories distinguish between intuitive reasoning (System 1), which also contributes to the interpretation of sentences, and deliberative reasoning (System 2), which contributes to deduction especially in the case of inferences such as Modus Tollens (e.g., Evans, 2003; Evans \& Over, 2004; Johnson-Laird, 1983, chap. 6; Johnson-Laird, 2006; Schroyens, Schaeken, \& Handley, 2003; Stanovich, 1999; Wason \& Evans, 1975, pp. 7-10). The force of our results is that both these systems can contribute to the same conclusion: the deliberative system yields its main propositions, and the intuitive system yields its tense. There is accordingly an urgent need for an implementation of a dual-process theory showing how such an integrated response is made. 
Table A1

The materials in Portuguese (and translated into English) for all three Experiments.

Materials for Experiment 1

Temporal conditionals

1. Se o doente tomar um antipirético, então a febre descerá.

If the patient takes an antipyretic drug, then his fever goes down.

2. Se o autor escrever o livro, então o editor publicá-lo-á.

If the author writes the book, then the publisher publishes it.

3. Se o aluno usar uma cábula, então a sua frequência será anulada.

If the student cheats in the test, then his score is annulled.

4. Se o estudante fizer uma pergunta, então o professor responderá.

If the pupil asks a question, then the professor responds.

5. Se o carro tiver um acidente, então os seguros pagarão.

If the car is in an accident, then the insurance company pays for the repairs.

6. Se o cliente fizer uma encomenda, então a mercadoria será enviada.

If the client makes an order, then the goods are shipped.

Control conditionals

7. Se o livro estiver em cima da mesa, então a caneta estará em cima da secretária.

If the book is on the table, then the pen is on the desk.

8. Se o biólogo fizer uma autópsia, então usará um bisturi.

If the biologist does an autopsy, then he uses a scalpel.

9. Se o escritório ficar em Moscovo, então o consultório ficará em Londres.

If the office is in Moscow then the clinic is in London.

10. Se o motor funcionar, então gastará combustível.

If the motor works then it burns fuel.

11. Se o sinal de aviso estiver aceso, então a rede estará electrificada.

If the warning light is on then the fence is electrified.

12. Se a vogal for o "I", então a consoante será o " $M$ ".

If the vowel is an 'I' then the consonant is an ' $M$ '.

Materials for Experiment 2

Temporal disjunctions

1. A Elsa fecha o negócio ou é despedida.

Either Elsa closes the deal or she is fired.

2. Tomás não compra o carro ou vai à falência.

Either Tomás doesn't buy the car or he goes broke.

Control disjunctions

3. A Joana lê o livro ou vê televisão.

Either Joana reads the book or she watches TV.

4. A Francisca não pensa em voz alta ou ela incomoda a colega de quarto.

Either Francisca doesn't think aloud or she bothers her roommate.

Temporal conditionals

5. Se o Luís não fechar o negócio então ele será despedido.

If Luís doesn't close the deal, then he is fired.

6. Se a Carla comprar o carro, então ela irá à falência.

If Carla buys the car, then she goes broke.

Control Conditionals

7. Se o Norberto não ler o livro, então ele verá televisão.

If Norberto doesn't read the book then he watches television.

8. Se o Paulo pensar alto, então ele incomodará o colega do quarto.

If Paulo thinks aloud, then he bothers his roommate.

Materials for Experiment 3

(In the original Portuguese, on average the questions had 21 syllables and the standard deviation of syllabic length did not reach one syllable $(S D=.77)$. This counterbalancing is lost in translation.)

Temporal Problems (in which the four questions occur on trials with different participants)

1. Se a duquesa ouvir as badaladas, então sentirá um arrepio nas costas.

Se a duquesa sentir um arrepio nas costas, então apertará o casaco.

A duquesa ouve as badaladas.

A duquesa ouve as badaladas antes de apertar o casaco?

A duquesa ouve as badaladas depois de apertar o casaco?

A duquesa aperta o casaco antes de ouvir as badaladas?

A duquesa aperta o casaco depois de ouvir as badaladas?

If the duchess hears the bell ringing, then she feels a shiver down her back.

If the duchess feels a shiver down her back, then she tightens her coat.

The duchess hears the bell ringing.

Did the duchess hear the bell ringing before she tightened her coat?

Did the duchess hear the bell ringing after she tightened her coat?

Did the duchess tighten her coat before she heard the bell ringing?

Did the duchess tighten her coat after she heard the bell ringing? 
Table A1 (continued)

Se a funcionária cheirar o fumo, então pensará que há fogo no escritório.

Se a funcionária pensar que há fogo no escritório, então pegará no telefone.

A funcionária cheira o fumo.

A funcionária cheira o fumo antes de pegar no telefone?

A funcionária cheira o fumo depois de pegar no telefone?

A funcionária pega no telefone antes de cheirar o fumo?

A funcionária pega no telefone depois de cheirar o fumo?

If the clerk smells smoke, then she thinks that there is a fire in the office.

If the clerk thinks that there is a fire in the office, then she picks up the phone.

The clerk smells smoke.

Did the clerk smell smoke before she picked up the phone?

Did the clerk smell smoke after she picked up the phone?

Did the clerk pick up the phone before she smelt smoke?

Did the clerk pick up the phone after she smelt smoke?

3.

Se o emigrante vir o filho, então sentirá um aperto no coração.

Se o emigrante sentir um aperto no coração, então apoiar-se-á no corrimão.

O emigrante vê o filho.

O emigrante vê o filho antes de se apoiar no corrimão?

O emigrante vê o filho depois de se apoiar no corrimão?

O emigrante apoia-se no corrimão antes de ver o filho?

O emigrante apoia-se no corrimão depois de ver o filho?

If the emigrant sees his son, then he feels a wrench in his heart.

If the emigrant feels a wrench in his heart, then he grabs the handrail.

The emigrant sees his son.

Did the emigrant see his son before he grabbed the handrail?

Did the emigrant see his son after he grabbed the handrail?

Did the emigrant grab the handrail before he saw his son?

Did the emigrant grab the handrail after he saw his son?

4.

Se o electricista tocar no fio, então apanhará um choque na mão.

Se o electricista apanhar um choque na mão, então dirá um palavrão.

O electricista toca no fio.

O electricista toca no fio antes de dizer um palavrão?

O electricista toca no fio depois de dizer um palavrão?

O electricista diz um palavrão antes de tocar no fio?

O electricista diz um palavrão depois de tocar no fio?

If the electrician touches the wire, then he gets a shock in his hand.

If the electrician gets a shock in his hand, then he swears.

The electrician touches the wire.

Did the electrician touch the wire before he swore?

Did the electrician touch the wire after he swore?

Did the electrician swear before he touched the wire?

Did the electrician swear after he touched the wire?

Spatial Problems (in which the four questions occur on trials with different participants)

Se o sinal combinado estiver no chão, então haverá uma nota na janela.

Se houver uma nota na janela, então a pistola carregada estará no telhado.

O sinal combinado está no chão.

O sinal combinado está acima da pistola carregada?

O sinal combinado está abaixo da pistola carregada?

A pistola carregada está acima do sinal combinado?

A pistola carregada está abaixo do sinal combinado?

If the agreed mark is on the floor, then there is a note on the window.

If there is a note on the window, then the loaded pistol is on the roof.

The agreed mark is on the floor.

Is the agreed mark above the loaded pistol?

Is the agreed mark below the loaded pistol?

Is the loaded pistol above the agreed mark?

Is the loaded pistol below the agreed mark?

Se o jardineiro moçambicano estiver na cave, então a criada estará no rés-do-chão.

Se a criada estiver no rés-do-chão, então mordomo estará no primeiro andar.

O jardineiro moçambicano está na cave.

O jardineiro moçambicano encontra-se acima do mordomo?

O jardineiro moçambicano encontra-se abaixo do mordomo?

O mordomo encontra-se acima do jardineiro moçambicano?

O mordomo encontra-se abaixo do jardineiro moçambicano?

If the Mozambiquean gardener is in the basement, then the maid is on the ground floor.

If the maid is on the ground floor, then the butler is on the first floor.

The Mozambiquean gardener is in the basement.

Is the Mozambiquean gardener above the butler? 
Table A1 (continued)

Is the Mozambiquean gardener below the butler?

Is the butler above the Mozambiquean gardener?

Is the butler below the Mozambiquean gardener?

7.

Se o chip copiado estiver escondido no pedal, então haverá um autocolante no volante.

Se houver um autocolante no volante, então as indicações específicas estarão no espelho.

O chip copiado está escondido no pedal.

O chip copiado está acima das indicações específicas?

O chip copiado está abaixo das indicações específicas?

As indicações específicas estão acima do chip copiado?

As indicações específicas estão abaixo do chip copiado?

If the [copied] chip is hidden in the pedal, then there is a sticker on the steering wheel.

If there is a sticker on the steering wheel, then the specific directions are on the mirror.

The chip is hidden in the pedal.

Is the chip above the specific directions?

Is the chip below the specific directions?

Are the specific directions above the chip?

Are the specific directions below the chip?

8.

Se a tatuagem colorida estiver na testa, então o brinco estará no nariz.

Se o brinco estiver no nariz, então o piercing metálico estará no lábio.

A tatuagem colorida está na testa.

A tatuagem colorida está acima do piercing metálico?

A tatuagem colorida está abaixo do piercing metálico?

O piercing metálico está acima da tatuagem colorida?

O piercing metálico está abaixo da tatuagem colorida?

If the colored tattoo is on his forehead, then the earring is in his nose.

If the earring is in his nose, then the metal piercing is in his lip.

The colored tattoo is on his forehead.

Is the colored tattoo above the metal piercing?

Is the colored tattoo below the metal piercing?

Is the metal piercing above the colored tattoo?

Is the metal piercing below the colored tattoo?

Double relation problems (in which the eight questions occur on trials with different participants)

9.

Se o verme devorar as folhas, então passará do tronco para as raízes.

Se o verme passar para as raízes, então as raízes libertarão veneno.

O verme devora as folhas.

O verme devora as folhas antes de as raízes libertarem veneno?

$\mathrm{O}$ verme devora as folhas depois de as raízes libertarem veneno?

As raízes libertam veneno antes de o verme devorar as folhas?

As raízes libertam veneno depois de o verme devorar as folhas?

No começo o verme está localizado acima das raízes?

No começo o verme está localizado acima das folhas?

No final o verme está localizado abaixo das raízes?

No final o verme está localizado abaixo das folhas?

If the worm eats up the leaves, then it goes from the trunk to the root.

If the worm goes to the root, then the root releases poison.

The worm eats up the leaves.

Did the worm eat up the leaves before the root released poison?

Did the worm eat up the leaves after the root released poison?

Did the root release poison before the worm ate up the leaves?

Did the root release poison after the worm ate up the leaves?

At the start, was the worm above the root?

At the start, was the worm above the leaves?

At the end, was the worm below the root?

At the end, was the worm above the leaves?

Se a escultura cair da prateleira, então baterá no chão da sala.

Se a escultura bater no chão da sala, então o vaso chinês tombará.

A escultura cai da prateleira.

A escultura cai da prateleira antes de o vaso chinês tombar?

A escultura cai da prateleira depois de o vaso chinês tombar?

$O$ vaso chinês tomba antes de a escultura cair da prateleira?

$O$ vaso chinês tomba depois de a escultura cair da prateleira?

No começo a escultura posiciona-se acima do chão?

No começo a escultura está acima da prateleira?

No final a escultura encontra-se debaixo do chão?

No final a escultura encontra-se abaixo da prateleira?

If the sculpture falls off the shelf, then it hits the living room floor.

If the sculpture hits the living room floor, then the Chinese vase falls over.

The sculpture falls from the shelf.

Did the sculpture fall off the self before the Chinese vase fell over? 
Did the sculpture fall off the self after the Chinese vase fell over? Did the Chinese vase fall over before the sculpture fell off the self? Did the Chinese vase fall over after the sculpture fell off the self? At the start, was the sculpture above the floor? At the start, was the sculpture above the shelf? At the end, was the sculpture below the floor? At the end, was the sculpture below the shelf?

11.

Se os invasores passarem o fosso, então escalarão a muralha do castelo.

Se os invasores escalarem a muralha do castelo, então matarão o guarda. Os invasores passam o fosso.

Os invasores passam o fosso antes de matar o guarda? Os invasores passam o fosso depois de matar o guarda?

Os invasores matam o guarda antes de passar o fosso? Os invasores matam o guarda depois de passar o fosso? No começo os invasores encontram-se acima da muralha? No começo os invasores encontram-se acima do fosso? No final os invasores posicionam-se abaixo da muralha? No final os invasores posicionam-se abaixo do fosso? If the invaders cross the ditch, then they climb the castle's wall. If the invaders climb the castle's wall, then they kill the guard. The invaders cross the ditch.

Did the invaders cross the ditch before they killed the guard? Did the invaders cross the ditch after they killed the guard? Did the invaders kill the guard before they crossed the ditch? Did the invaders kill the guard after they crossed the ditch? At the start, were the invaders above the wall? At the start, were the invaders above the ditch? At the end, were the invaders below the wall? At the end, were the invaders below the ditch?

Se a infecção da anca passar, então o joelho do paciente infectará. Se o joelho do paciente infectar, então o doutor mudará a medicação. A infecção da anca passa.

A infecção da anca passa antes de o doutor mudar a medicação? A infecção da anca passa depois de o doutor mudar a medicação?

$\mathrm{O}$ doutor muda a medicação antes de a infecção da anca passar?

O doutor muda a medicação depois de a infecção da anca passar? No começo a infecção localiza-se acima do joelho?

No começo a infecção localiza-se acima da anca?

No final a infecção está localizada abaixo do joelho?

No final a infecção está localizada abaixo da anca?

If the hip infection disappears, then the patient's knee gets infected.

If the patient's knee gets infected, then the doctor changes the medication. The hip infection disappears.

Did the hip infection disappear before the doctor changed the medication? Did the hip infection disappear after the doctor changed the medication? Did the doctor change the medication before the hip infection disappeared? Did the doctor change the medication after the hip infection disappeared? At the start, was the infection localized above the knee? At the start, was the infection localized above the hip? At the end, was the infection localized below the knee? At the end, was the infection localized below the hip?

Se o soldado for atingido na torre, então cairá para a trincheira.

Se o soldado cair para a trincheira, então perderá a arma.

O soldado é atingido na torre.

O soldado é atingido na torre antes de perder a arma?

O soldado é atingido na torre depois de perder a arma?

O soldado perde a arma antes de ser atingido na torre?

O soldado perde a arma depois de ser atingido na torre?

No começo o soldado encontra-se acima da trincheira?

No começo o soldado posiciona-se acima da torre?

No final o soldado localiza-se abaixo da trincheira?

No final o soldado está localizado abaixo da torre?

If the soldier in the tower is hit, then he falls into the trench.

If the soldier falls into the trench, then he loses his gun.

The soldier is hit.

Was the soldier in the tower hit before he lost his gun?

Was the soldier in the tower hit after he lost his gun?

Did the soldier lose his gun before he was hit in the tower?

Did the soldier lose his gun after he was hit in the tower? 
Table A1 (continued)

At the start, was the solder above the trench?

At the start, was the solder above the tower?

At the end, was the solder below the trench?

At the end, was the solder below the tower?

14.

Se o técnico terminar o telhado, então irá buscar o material ao primeiro andar.

Se o técnico for buscar o material ao primeiro andar, então verá o segurança.

O técnico termina o telhado.

O técnico termina o telhado antes de ver o segurança?

O técnico termina o telhado depois de ver o segurança?

O técnico vê a segurança antes de terminar o telhado?

O técnico vê a segurança depois de terminar o telhado?

No começo o técnico está acima do primeiro andar?

No começo o técnico encontra-se acima do telhado?

No final o técnico encontra-se abaixo do primeiro andar?

No final o técnico localiza-se abaixo do telhado?

If the builder finishes the roof, then he goes to the first floor to get materials.

If the builder goes to the first floor to get materials, then he sees the security person.

The builder finishes the roof.

Did the builder finish the roof before he saw the security person?

Did the builder finish the roof after he saw the security person?

Did the builder see the security person before he finished the roof?

Did the builder see the security person after he finished the roof?

At the start, was the builder above the first floor?

At the start, was the builder above the roof?

At the end, was the builder below the first floor?

At the end, was the builder below the roof?

15. Se a empregada limpar a secretária, então porá as pastas no chão.

Se a empregada puser as pastas no chão, então encontrará um anel.

A empregada limpa a secretária.

A empregada limpa a secretária antes de encontrar um anel?

A empregada limpa a secretária depois de encontrar um anel?

A empregada encontra um anel antes de limpar a secretária?

A empregada encontra um anel depois de limpar a secretária?

No começo as pastas estão localizadas acima do chão?

No começo as pastas encontram-se acima da secretária?

No final as pastas estão localizadas debaixo do chão?

No final as pastas encontram-se abaixo da secretária?

If the maid cleans the desk, then she puts the folders on the floor.

If the maid puts the folders on the floor, then she finds a ring.

The maid cleans the desk.

Did the maid clean the desk before she found a ring?

Did the maid clean the desk after she found a ring?

Did the maid find a ring before she cleaned the desk?

Did the maid find a ring after she cleaned the desk?

At the start, were the folders above the floor?

At the start, were the folders above the desk?

At the end, were the folders below the desk?

At the end, were the folders below the floor?

Se o revisor ler o cabeçalho, então também lerá a nota no rodapé.

Se o revisor ler a nota no rodapé, então escreverá uma anotação.

$\mathrm{O}$ revisor lê o cabeçalho.

O revisor lê o cabeçalho antes de escrever uma anotação?

O revisor lê o cabeçalho depois de escrever uma anotação?

O revisor escreve uma anotação antes de ler o cabeçalho?

O revisor escreve uma anotação depois de ler o cabeçalho?

No começo o revisor lê um texto acima da nota do rodapé?

No começo o revisor lê um texto acima do cabeçalho?

No final o revisor lê um texto abaixo da nota do rodapé?

No final o revisor lê um texto abaixo do cabeçalho?

If the reviewer reads the header, then he also reads the footnote.

If the reviewer reads the footnote, then he writes an annotation.

The reviewer reads the header.

Did the reviewer read the header before he wrote an annotation?

Did the reviewer read the header after he wrote an annotation?

Did the reviewer write an annotation before he read the header?

Did the reviewer write an annotation after he read the header?

At the start, did the reviewer read a text above the footnote?

At the start, did the reviewer read a text above the header?

At the end, did the reviewer read a text below the footnote?

At the end, did the reviewer read a text below the header? 


\section{Acknowledgements}

This research was supported in part by a grant from the Portuguese Foundation for Science and Technology (FCT) to the first two authors, and by a grant from the National Science Foundation Grant No. SES 0844851 to the third author to study deductive and probabilistic reasoning. We thank Ruth Byrne, Geoffrey Goodwin, and Sangeet Khemlani, for advice, and David O'Brien and two anonymous reviewers for their helpful criticisms of an earlier version of the paper.

We also thank to Marta Couto, Célia Rasga e Ana Catarina Perpétuo for helping to prepare the experiments.

\section{Appendix A}

See Table A1.

\section{References}

Allen, J. F., \& Ferguson, G. (1994). Actions and events in interval temporal logic. Journal of Logic and Computation, 4, 531-579.

Braine, M. D. S. (1978). On the relation between the natural logic of reasoning and standard logic. Psychological Review, 85, 1-21.

Braine, M. D. S., \& O’Brien, D. P. (1998). Mental logic. Mahwah, NJ: Erlbaum.

Evans, J. S. B. T. (2003). In two minds: Dual process accounts of reasoning. Trends in Cognitive Sciences, 7, 454-459.

Evans, J. S. B. T., \& Over, D. E. (2004). If. Oxford: Oxford University Press.

Goodwin, G. P., \& Johnson-Laird, P. N. (submitted for publication). Reasoning as simulation.
Johnson-Laird, P. N. (1983). Mental models: Towards a cognitive science of language, inference, and consciousness. Cambridge, Mass.: Harvard University Press.

Johnson-Laird, P. N. (2006). How we reason. Oxford: Oxford University Press.

Johnson-Laird, P. N., \& Byrne, R. M. J. (1991). Deduction. Hillsdale, NJ: Lawrance Erlbaum Associates.

Johnson-Laird, P. N., \& Byrne, R. M. J. (2002). Conditionals: A theory of meaning, pragmatics, and inference. Psychological Review, 109, 646-678.

Johnson-Laird, P. N., Girotto, V., \& Legrenzi, P. (2004). Reasoning from inconsistency to consistency. Psychological Review, 111, 640-661.

Miller, G. A., \& Johnson-Laird, P. N. (1976). Language and perception. Cambridge: Cambridge University Press; Cambridge, MA: Harvard University Press.

Ormerod, T. C., \& Richardson, J. (2003). On the generation and evaluation of inferences from single premises. Memory E Cognition, 31, 467-478.

Quelhas, A. C., Johnson-Laird, P. N., \& Juhos, Cs. (2010). The modulation of conditional assertions and its effects on reasoning. The Quarterly Journal of Experimental Psychology, 63, 1716-1739.

Rips, L. J. (1994). The psychology of proof: Deductive reasoning in human thinking. Cambridge: MIT Press.

Schaeken, W. S., Johnson-Laird, P. N., \& d'Ydewalle, G. (1996a). Mental models and temporal reasoning. Cognition, 60, 205-234.

Schaeken, W. S., Johnson-Laird, P. N., \& d'Ydewalle, G. (1996b). Tense, aspect, and temporal reasoning. Thinking and Reasoning, 2, 309-327.

Schroyens, W., Schaeken, W., \& Handley, S. (2003). In search of counter examples: Deductive rationality in human reasoning. Quarterly Journal of Experimental Psychology, 56A, 1129-1145.

Stanovich, K. E. (1999). Who is rational? Studies of individual differences in reasoning. Mahwah, NJ: Erlbaum.

Van der Henst, J.-B., Yang, Y., \& Johnson-Laird, P. N. (2002). Strategies in sentential reasoning. Cognitive Science, 26, 425-468.

Wason, P. C., \& Evans, J. St. B. T. (1975). Dual processes in reasoning? Cognition, 3, 141-154. 